\title{
CONVERSION STRATEGIES FOR DUTCH PRIMARY SCHOOLS: PRACTICE AND REFINEMENT
}

\author{
Dolf BROEKHUIZEN (D) ${ }^{1^{*}}$, Monique ARKESTEIJN (iD) ${ }^{2}$, Peter de JONG (iD ${ }^{3}$, \\ Frido van NIEUWAMERONGEN (1) 4 \\ ${ }^{1}$ Dolf Broekhuizen Architecture Historian, Rotterdam, the Netherlands \\ 2, 3 Department of Management in the Built Environment, Faculty of Architecture and the Built Environment, \\ Delft University of Technology, the Netherlands \\ ${ }^{4}$ Arconiko, Rotterdam, the Netherlands
}

Received 31 October 2019; accepted 11 June 2020

\begin{abstract}
Handbooks on strategic real estate management are generally based on four strategies for functional adjustment of the building: conversion, expansion, renovation and adaptive reuse. And on a strategic level, this classification in adjustment strategies does work for real estate in general. But when looking at Dutch primary schools as a specific type of real estate, reality can be and is more nuanced. Other accommodation strategies came to the fore in a study into the spatial adaptation of primary schools and children's centres in the Netherlands. An analysis of 100 school buildings studied in the Atlas of School Building (published in Dutch as Scholenbouwatlas) revealed that nine main strategies were prevalent in practice. This refinement of the strategies fits (better) with integrated conversion actions of primary schools in which several aspects are solved together. In the following article these strategies are analysed and discussed in a theoretical context. The conclusion of the analyses is that the existing general models in the strategic handling of the building stock in the case of specific real estate of primary schools can be refined.
\end{abstract}

Keywords: schools, strategy, adaptation, renovation, conversion strategies, children's centre.

\section{Introduction}

Many handbooks on real-estate strategies for the adaptation of buildings mention four strategies: conversion, expansion, renovation and adaptive reuse (for example: Vermeulen \& Wieman, 2016). But an analysis of the practice of the adaptation of 100 primary schools in the Netherlands made clear that in many cases the four strategies appeared to be too schematic and theoretical. Many more diffuse forms occurred in the schools studied. Based on material-spatial criteria, nine strategies that have appeared in practice could be defined, which were further investigated in this study.

Why is the theme of conversion strategies for primary schools of significance? Some commentators argue that the almost obvious desire to improve the educational process by building a new school is obsolete, or at least not thought through. Often a conversion of an existing school is a very good solution, or even offers (economic and spatial) advantages over new buildings. Integrated refurbishments actions are needed (Österreicher \& Geissler, 2016).
The arguments for adjustments are urgent and varied in the Netherlands. However, hardly any analytical research has been done on adapting the spatial environment for primary education to a mix of new educational insights, developments in society or physical characteristics (Algemene Rekenkamer, 2016). This may be because the relationship between all these factors is extremely complex (De Vrieze \& Moll, 2015). Various researchers focus on partial aspects, as shown in the discussion below, which provides an overview of the state of affairs of research into functional improvement or functional extension of primary schools and children's centres in the Netherlands. The authors of this paper place the theme of conversion strategies for Dutch primary schools centrally, and analyse the results of evidence-based practice in the context of general real estate strategies in literature. This paper aims to reveal that a more nuanced strategy offers a more realistic view on accommodation strategies, than the often used general strategies conversion, expansion, renovation and adaptive reuse.

${ }^{*}$ Corresponding author. E-mail: info@dolfbroekhuizen.nl 
An overview of recent developments within primary education can give more insight in the reasons for integrated refurbishment. Educational facilities for young children in the Netherlands are changing rapidly, as evidenced by the development of broad schools or community schools (in Dutch called brede scholen) since 1995 and integrative children's centres since 2010 (e.g. EIB, 2013). The functioning of primary schools as part of multifunctional building with integrated full-day child care for primary school and kindergarten groups is both a design and organizational issue. Besides this, there was a paradigm shift in education. The Netherlands Court of Audit concluded in a study into buildings for primary education in this country that the functional quality was under pressure because of the following developments: "The introduction of inclusive education, the need for more room for differentiation, digitization of education and development of new forms of education" (Algemene Rekenkamer, 2016). Besides these aspects of multifunctional use, the problem is the poor performance of the (existing) monofunctional building. The Chief Government Architect in the Netherlands concluded in a report in 2009, based on scientific research, that in circa 80 per cent of the schools the indoor climate is insufficient (Van der Pol et al., 2009).

\section{Structure of the paper}

The paper is structured as follows. After the introduction, the research method is explained (Part 1). The findings are presented in Part 2. The strategies for conversion and renovation will be discussed when comparing the strategies in this article with the standard strategies. To present a relevant context, the findings are embedded with the existing literature and context. Part 3 presents the literature research that focuses on the background of conversion of primary school buildings in different contexts and abroad. Part 4 presents some discussions on the findings. This paper ends with the conclusions.

\section{Research methods}

In this paper general conversion strategies in literature are compared with conversion strategies of 100 Dutch primary schools and children's centres. The research into the 100 case studies was carried out in the period 2012-2015 for the Atlas of School Building (Broekhuizen, 2015; Van Nieuwamerongen \& Broekhuizen, 2015). The main research question in this paper is: how does general conversion strategies relate with the strategies that appeared in the 100 case studies in the Atlas of School Building? To answer this question the authors analysed the conversion strategies that appeared in the 100 case studies with insights from (peer reviewed) literature of the last ten years on this subject. To compare the outcomes of the research with international findings and embed the analyses of practice with international findings, the team searched Scopus for relevant literature.
From June 2018 to June 2019 international articles in Scopus were checked with English keywords from education, architecture and real estate in the combined fields of words in title, abstract and keywords. Initially, many results were related to change of the educational process, and not to the building. Or they dealt with other forms of education than primary education. So the research is focused on specific combinations. The authors focused on buildings for primary education because renovation or conversion in other sectors (such as secondary education or social housing) has its own specific context and problems. The collected data were reviewed, and if they seemed relevant, the abstract was read. The articles seemed relevant due to their title and abstract were read. A test with Dutch, German and French keywords did not produce any new hits.

\section{Findings}

\subsection{Nine conversion strategies for primary education buildings}

In literature on the strategic management of buildings the options are grouped in four main strategies: conversion, expansion, renovation and adaptive reuse (Vermeulen \& Wieman, 2016). This categorization is based on aspects that are typical for the theoretical strategies: physical/material change, spatial change, alteration of the building volume, and functional adjustment. Besides these four mentioned strategies two other options are possible: sale and demolition, but these are not relevant for conversion of existing buildings. To compare the four general real estate conversion strategies with the case studies in the Scholenbouwatlas, it must be cleared out what the authors of this paper mean with the practice of nine strategies in Dutch school buildings and children's centres (Van Nieuwamerongen \& Broekhuizen, 2015). The following nine conversion strategies can be defined: 1) "Precise interventions", 2) "Break open", 3) "Restore original qualities", 4) "Continue route", 5) "Use of surplus space", 6) "Old and new", 7) "Put together", 8) "Adaptive reuse" and, finally, 9) "Total approach". The criteria of the types of conversions refer to the physical-spatial characteristics of the function change. Some remarks must be mentioned here according to this grouping. The authors state in their explanation that the nine strategies can have variants in practice: multiple strategies can occur simultaneously in a building (Van Nieuwamerongen \& Broekhuizen, 2015). Nevertheless, it makes sense to name them because this ensures that they become recognizable as a strategy. From the same point of view, the strategies were typified on the basis of an icon in the book (Figure 1). Below is a clarification in more detail of what each strategy in the Atlas of School Building means (Table 1). The strategies are illustrated with realistic examples that are typical of that strategy (Figures 2.1-2.9). 


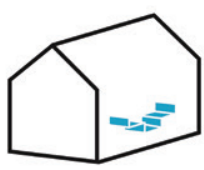

1.
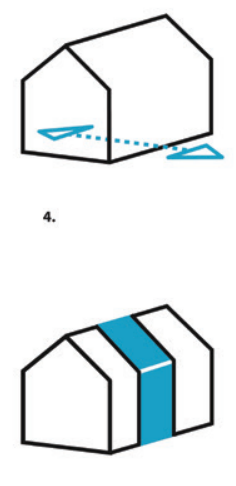
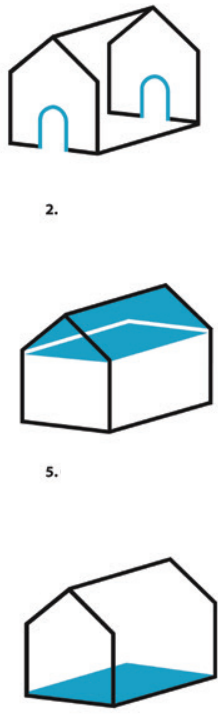
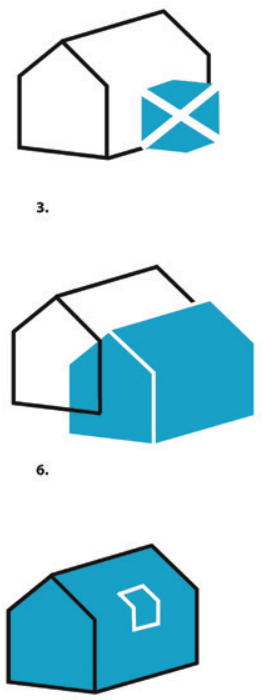

Figure 1. Icons of the nine conversion strategies: 1) "Precise interventions", 2) "Break open", 3) "Restore original qualities", 4) "Continue route", 5) "Use of surplus space", 6) “Old and new”, 7) "Put together", 8) "Adaptive reuse",

9) “Total approach" (drawings Roswitha Abraham, source: Van Nieuwamerongen \& Broekhuizen, 2015)

Table 1. Table of strategies in the Atlas of School Building. Explanation of the nine conversion strategies (source: Van Nieuwamerongen \& Broekhuizen, 2015)

\begin{tabular}{|c|c|c|}
\hline Atlas of School Building Strategies & & \\
\hline $\begin{array}{l}\text { 1. Precise interventions } \\
\text { The small, precise procedure is subtle. } \\
\text { The intervention strategy is often focused } \\
\text { on the interior and is realized with the } \\
\text { help of elements such as stairs, walls and } \\
\text { lifts. At first glance, this strategy may be } \\
\text { very similar to the ad hoc remodelling } \\
\text { of a school, but where ad hoc solutions } \\
\text { have no coherence in the interventions, } \\
\text { the "precise interventions" are part of } \\
\text { a coherent idea, so that the school as a } \\
\text { whole progresses }\end{array}$ & $\begin{array}{l}\text { 2. Break open } \\
\text { In this strategy, breaking open } \\
\text { forms the basis for the new vision } \\
\text { of the school building. A vision } \\
\text { where the open and varied teaching } \\
\text { method goes hand in hand with the } \\
\text { grandeur of the historical building. } \\
\text { The character of the existing } \\
\text { building is maintained, but the } \\
\text { openings and breakthroughs are } \\
\text { visible as a contemporary addition }\end{array}$ & $\begin{array}{l}\text { 3. Restore original qualities } \\
\text { The return to the original qualities is based on } \\
\text { peeling. The unity and cohesion that has been } \\
\text { lost over the course of time is restored and used } \\
\text { as a new positive force. By deleting all of the } \\
\text { added layers, literally and figuratively, space is } \\
\text { created to design a new building and to develop } \\
\text { a future-proof vision }\end{array}$ \\
\hline $\begin{array}{l}\text { 4. Continue route } \\
\text { With this strategy, the conversion is } \\
\text { merged with the logical structure of } \\
\text { the existing building: the routing, as } \\
\text { determined in the spatial layout and } \\
\text { placement of volumes. This new structure } \\
\text { is often provided with more significance } \\
\text { through multiple uses. Due to the design } \\
\text { and proper zoning of the functions, } \\
\text { the rooms meet the requirements of a } \\
\text { comfortable indoor climate }\end{array}$ & $\begin{array}{l}\text { 5. Use of surplus space } \\
\text { In this conversion strategy, existing } \\
\text { elements such as a patio, a large } \\
\text { storey height or a wide corridor are } \\
\text { considered as options for changing } \\
\text { the school building. Using the } \\
\text { building's surplus space for new } \\
\text { functions requires due care. Crucial } \\
\text { is the demonstrable need for the } \\
\text { new function. Otherwise the extra } \\
\text { spaces will soon become useless }\end{array}$ & $\begin{array}{l}\text { 6. Old and new } \\
\text { The old school building is too small for the } \\
\text { requirements of the school. But the quality is } \\
\text { still good. In those cases, the school is often } \\
\text { refurbished, supplemented by a new extension, } \\
\text { next to or on the building. Of all strategies, } \\
\text { this is one of the most radical physically: } \\
\text { the existing building is tackled and new } \\
\text { construction is realized }\end{array}$ \\
\hline $\begin{array}{l}\text { 7. Put together } \\
\text { With this strategy, multiple buildings } \\
\text { are merged into one complex. The } \\
\text { buildings remain, but the functions and } \\
\text { organizations are rearranged. The merging } \\
\text { of building clusters into a new whole } \\
\text { often takes shape by adding a connecting } \\
\text { piece. The spatial and organizational } \\
\text { cohesion creates a new organization that } \\
\text { is more than the sum of its parts }\end{array}$ & $\begin{array}{l}\text { 8. Adaptive reuse } \\
\text { Reuse is relevant in connection } \\
\text { with the reuse problem. Change } \\
\text { of function in the realization of } \\
\text { primary schools or reception } \\
\text { facilities is a promising strategy. } \\
\text { With this strategy, the space is used } \\
\text { differently, after modifications to the } \\
\text { existing building. The suitability of } \\
\text { the existing building is a condition } \\
\text { for change of function and adaptive } \\
\text { reuse. The location must also match } \\
\text { the new function }\end{array}$ & $\begin{array}{l}\text { 9. Total approach } \\
\text { The trick is to prevent the building from } \\
\text { becoming the sum of the interventions. With } \\
\text { this strategy, conversion, maintenance and } \\
\text { renovation are used to improve the spatial, } \\
\text { functional and technical quality in an integrated } \\
\text { manner. Renovation, as well as maintenance, } \\
\text { is often seen as a technical intervention, but } \\
\text { it is more. In the "total approach", technical } \\
\text { maintenance is linked to an integrated approach } \\
\text { in which cohesion is sought between functional, } \\
\text { spatial, climatic and technical interventions }\end{array}$ \\
\hline
\end{tabular}


Figure 2.1-2.9 present typical examples of conversion strategies in the Atlas of School Building: School name, city, architectural office, year of completion of conversion (drawings Thom Hoevenaar, source: Van Nieuwamerongen \& Broekhuizen, 2015).

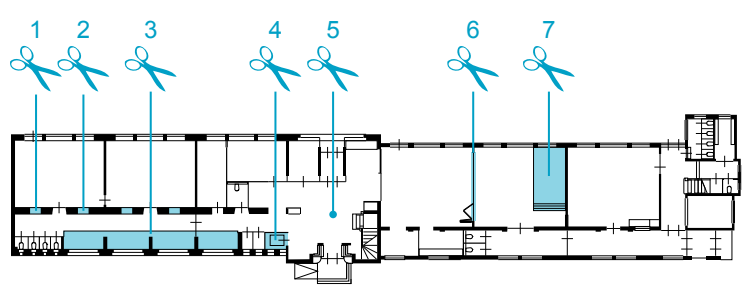

Figure 2.1. Precise intervention Special needs primary school St. Lucasschool, Rotterdam, Arconiko architects and Studio Deep, 2008

1 enlarge the inside window, 2 move the wardrobe, 3 add a workplace, 4 build in a lift, 5 widen the hall, 6 replace fixed wall with folding wall, 7 realize a stage

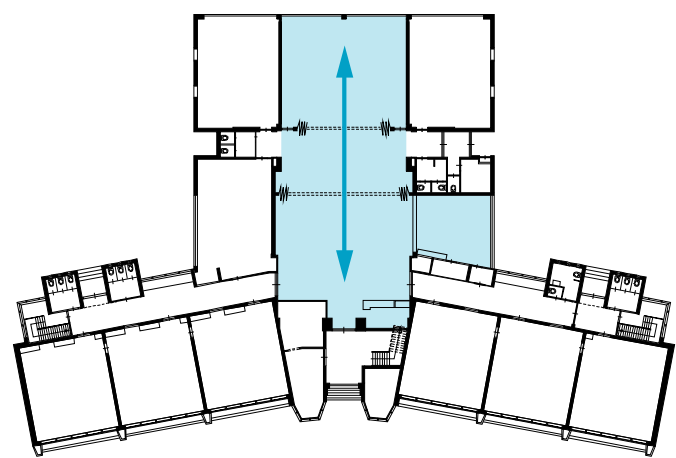

Figure 2.2. Break open

Primary school Gevers Deutz Terweeschool, Oegstgeest,

Stuurman and Partners, 2006

Open, enlarge sightline, widen

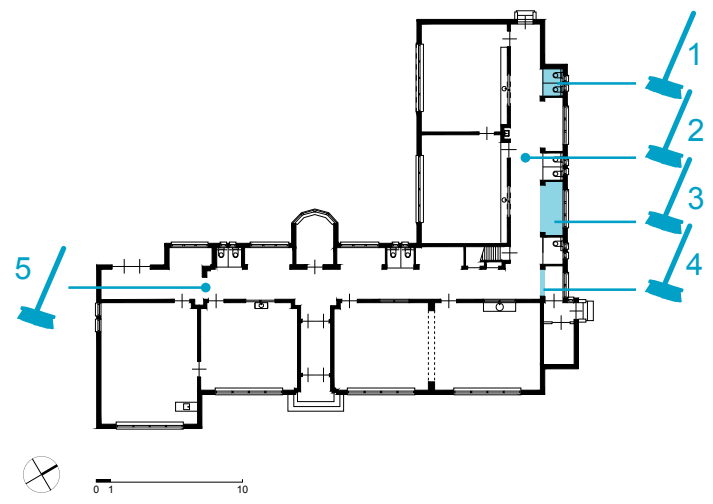

Figure 2.3. Restore original qualities

Primary school Geuzenschip, Brielle, Atelier PRO, 2011

1 repair original sanitary facilities, 2 restore tilework, 3 remove added storage and open niche, 4 remove the added door, 5 restore route

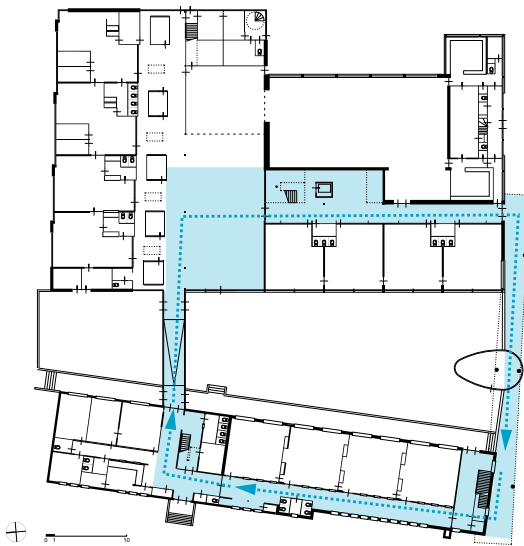

Figure 2.4. Continue route Community school De Bennekel, Eindhoven, KdV architectuur, 2007

Coloured: route after extensions

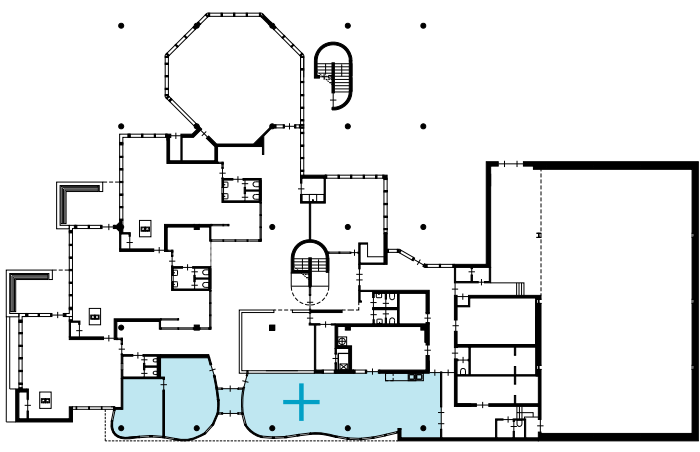

Figure 2.5. Use of surplus space Primary school Buitenveldertse Montessorischool, Amsterdam, Berger Barnett Architects, 2010 Coloured: utilized surplus space

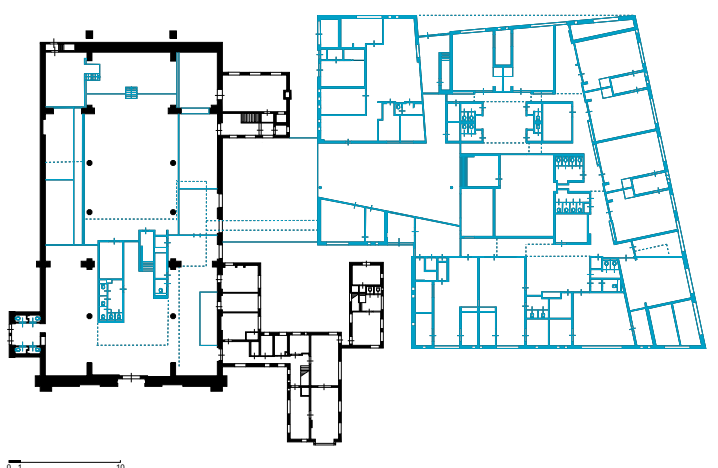

Figure 2.6. Old and new

Community school and community centre Huis van de Heuvel, Breda, Atelier PRO, 2012

Black: original building, coloured: added parts 


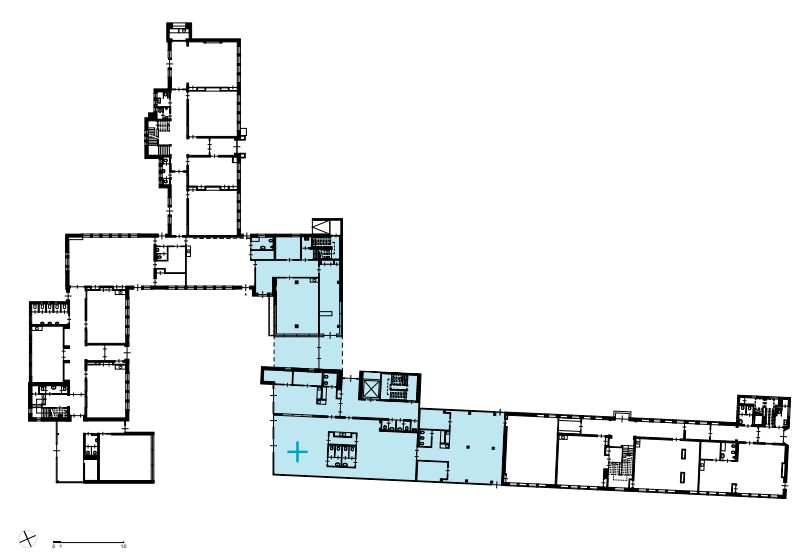

Figure 2.7. Put together Community school Spilcentrum De Trinoom, Eindhoven, Architecten En En, 2009 Coloured: connecting component

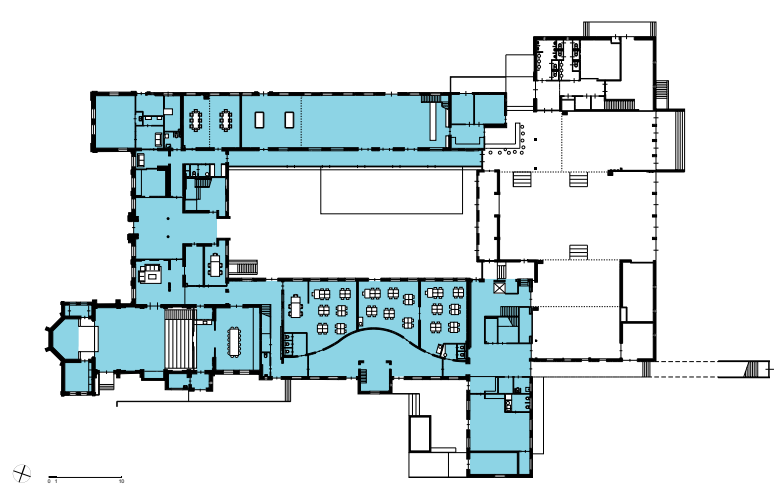

Figure 2.8. Adaptive reuse

Primary school Edith Stein and community centre, Zijtaart

(Veghel), Leenders architecten, 2011

Coloured: original building with new function

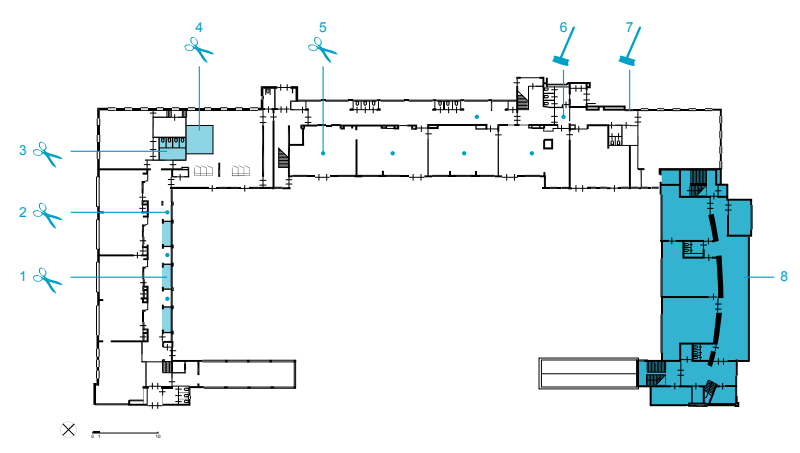

Figure 2.9. Total approach

Primary school Vijfde Montessorischool Watergraafsmeer, Amsterdam, Hans Kuiper, Andre van Stigt, 2011; right part: Villa Bons, HenNK, Studio Ai, 2002

1 wardrobe replaced by work place, 2 sanitary removal, 3 fit in new sanitary facilities, 4 realize a stage, 5 rearrange group space, 6 maintenance of tile work, 7 restore original window frames, 8 component with a new function

Figure 2. Nine typical examples of conversion strategies
A detailed comparative analyses of the nine strategies, mentioned in Table 1, carried out for this paper, shows that the strategy most frequently applied within the 100 case studies is "Old and new". In this strategy a part of the existing building is changed or a new part is added to make new or different uses possible. Another common strategy is "Use of surplus space" where a part of the building, such as a former storage room, an attic or a patio, is given a new function and is used more intensively. Another common feature is the "Adaptive reuse" strategy, where a building is reused as a primary school or children's centre. This often occurs in practice, such as the transformation of a school with one educational function into one with a different educational function. The last strategy that occurs more than ten times in the Atlas of School Building is the "Precise intervention". A small part of the building is changed so that a new function becomes possible on the spot.

The "Put together" strategy occurs relatively less often (fewer than ten times) in this study, but it is still a common solution. In the "Put together" strategy, two or three buildings next to each other are merged by an intermediary part, and together they fulfil a new function as a single complex. In another solution, "Continue route", the intervention is characterized as a reinforcement of the existing route in the building. In the "Break open" strategy, new connections in the existing building are made, such as between classrooms and corridors, or between classrooms, for example to change functional use or to create sightlines.

The strategies found least often are "Total approach" and "Restore original qualities". These occur in five cases or even less out of 100 in the Atlas of School Building. The "Total approach" strategy goes far beyond major maintenance or largescale technical renovation, but is aimed at an integrated intervention of renovation and function change. The emphasis here is on the combination of building and educational improvement rather than on improving either building-physical, building-technical qualities and/or building performance in relation to costs. Finally, in the last strategy, "Restore original qualities", small-scale interventions, which have taken place after the original construction, are cancelled out, cleaned up as it were. The table below lists the strategies and the number of times they occur in the Atlas of School Building (Table 2).

Table 2. Table of conversion strategies and the number of times they are found in the Atlas of School Building, total 100

\begin{tabular}{|l|c|}
\hline $\begin{array}{c}\text { Conversion strategy in the } \\
\text { Atlas of School Building }\end{array}$ & $\begin{array}{c}\text { Number of times found in } \\
\text { the Atlas of School Building }\end{array}$ \\
\hline Old and new (\#6) & 29 \\
\hline Use of surplus space (\#5) & 16 \\
\hline Adaptive reuse (\#8) & 14 \\
\hline Precise interventions (\#1) & 11 \\
\hline Continue route (\#4) & 8 \\
\hline Put together (\#7) & 8 \\
\hline Break open (\#2) & 6 \\
\hline Total approach(\#9) & 5 \\
\hline Restore original qualities (\#3) & 3 \\
\hline
\end{tabular}




\subsection{Comparison of conversion strategies in the Atlas of School Building with literature}

Four conversion strategies

To analyse how these conversion strategies in the Atlas of School Building relate to other strategies for the adaptation of primary schools, the authors of this paper consulted peer reviewed literature. Most of the studies relate conversion strategies to another context (see Part 3), and do not focus on the conversion strategy as the main theme. As a comparative strategy in the Dutch context, the authors found a more or less accepted standard for real estate strategies that is often used in the Netherlands (Prins, 1992; De Vries, 2007; Vermeulen \& Wieman, 2010; Den Heijer \& Van der Voordt, 2012; Den Heijer et al., 2013; Vermeulen \& Wieman, 2016). The often used standard model poses four types of intervention levels that can take place in existing buildings. The first three are based on functional prolongation, the fourth on functional change. The least drastic strategy for functional prolongation is "modification"; this changes the materialization of the building only. Modification can be understood as maintenance. "Conversion/renovation" has more impact: in addition to the material structure the spatial layout is also changed. Renovation is maintenance with a thorough adjustment and with a multi-year perspective. A more radical intervention is "expansion", where not only materialization and spatial layout, but also the volume of the building is altered. The most far-reaching is "adaptive reuse" (redeployment), where the function radically changes; the latter intervention is focused on a new use of the building. Table 3 gives an overview of the most important differences of the four spatial strategies. Other strategies include demolition and disposal, but they relate to the termination of use. In the research for this article, the last (demolition and disposal) and the first (maintenance) were disregarded.

\section{Comparison with standard model}

A comparison of these general strategies with those in the Atlas of School Building shows in the first place the difference in number of possibilities: four strategies in comparison with the nine used by Van Nieuwamerongen and Broekhuizen (2015) Further comparisons show that there is some partial overlap, and that the nine strategies often have more than one aspect in common. For example, the conversion can be a change of layout and also a volume expansion or a change of function, but the combination is not necessarily. For example, a "precise intervention", such as replacing a wall with a folding wall, or placing work furniture in a corridor, could be aimed at expanding the function (Figure 2.1). In the standard model that would mean a change of material and layout, but not of function (which is also the case here). And "Use of surplus space" refers to the change of function, such as using a former porch for an indoor after-school activity (Figure 2.5). In the standard model that is considered "expansion", but in this case only a small part of the building is altered within the contour (and not the figuration of the whole building). In fact, the standard model is based on a layered scheme of intervention, or a typology of intervention method, from relatively small interventions (modification and conversion) to those that are comprehensive (adaptive reuse).

\section{Intertwined interventions}

Further comparison of the standard model with the Atlas of School Building Strategies yields the following observation. In the Atlas of School Building, the characteristics are not a question of "yes or no" but of an integration that leads to a main theme, because the aspects of the Atlas of School Building can be combined. Van Nieuwamerongen and Broekhuizen (2015) give nine main strategies, but state that these are highlighted themes and that in practice they can also be applied simultaneously. The interventions are much more intertwined. That system is a fundamentally different model.

Furthermore, the examples show that the four basic strategies are applied mixed, in combination with each other. The nine strategies showcased could help to apply the more nuanced approach to a specific type of real estate (primary schools) than offered by the general standard models. The authors of this article hold a plea for a more detailed approach of accommodation strategies and a choice for integrated strategies. The existing standard strategies are abstract and used for all types of real estate, this paper shows that for primary schools and children's centres more nuanced strategies are possible and preferable.

Because there are hardly any specific peer reviewed publications dating form the last decade about conversions strategies of Dutch primary schools, it is interesting to mention some "grey" literature. There are a number of non-peer reviewed publications on the conversion of primary schools from the Netherlands and from neighbouring countries. Several of these strategies are focused on building volume and layout (Van Dam \& Spoormans, 2011; Scottish Government, 2009). An interesting study in a survey about recent international school buildings mentions the tendency in the United Kingdom to "use and refurbish the existing building stock to provide the

Table 3. Overview of the differences between the four general conversion strategies (source: Den Heijer et al., 2013)

\begin{tabular}{|c|c|c|c|c|}
\hline Conversion strategy and impact of change & Materialization & Spatial layout & Building volume & Functional use \\
\hline Modification (maintenance) & yes & no & no & no \\
\hline Conversion or renovation & yes & yes & no & no \\
\hline Extension & yes & yes & yes & no \\
\hline Redeployment (function change) & yes & yes & yes & yes \\
\hline
\end{tabular}


new schools", rather than build new ones (Evans, 2015). Although less systematically elaborated in the research approach, Evans' position on conversion characteristics appears to be in line with that of the researchers of the Atlas of School Building. Researchers involved in the Montag Stiftungen in Germany go a step further. They argue that it is not easy to name different strategies because the distinction is often not clear and strategies often occur in combination and mixed with each other. The researchers of the Montag Stiftungen do, however, showcase many strategies for case studies, focusing on building components, such as adapting classrooms, the auditorium, or the common area in a building (Montag Stiftungen, 2012; see also Montag Stiftung Jugend und Gesellschaft, 2017).

\section{Background}

\section{Conversion strategies of primary school buildings in} specific contexts

Findings in international literature about conversion strategies of primary school buildings or children's centres are varied in context and dimension. Most of them focus on one specific aspect, and do not focus on the strategy itself. For example, studies about the interaction of trends in education and pedagogy and the spatial change of primary school buildings range from details of the school interior and education programme to the analyses of school buildings in the neighbourhood. Several authors studied the relationship between building characteristics and education, but did not focus on conversion strategies (Emmelot et al., 2006; Van Merriënboer et al., 2014; Vos, 2015; Tondeur et al., 2015; Tennekes et al., 2017). The research that exists in the field of conversion of primary schools in the context of building technology and health point directly or indirectly to the importance of adapting the buildings to achieve the intended physical quality or to increase the efficiency of the educational process - for pupils, teachers and other staff alike (Van der Pol et al., 2009; Österreicher \& Geissler 2016; Bluyssen et al., 2018). In recent years, there is a major challenge for adapting primary school buildings in the Netherlands due to the maintenance and sustainability task, whereby the renovation of school buildings to make them energy-efficient is given priority in many municipalities (called the climate agreement). Considerable research effort has been made to study the decision-making process and lifecycle costs (De Jong \& Arkesteijn, 2014; SER, 2016; Kempinga \& Feddes, 2017). Various international researchers emphasize the desirability of an integrated design approach. Italian (Calice et al., 2012); Austrian (Stocker et al., 2015) and Portugese studies (Brás et al., 2015) show examples of an integral approach using lifecycle costs.

\section{Process considerations and management and conversion strategies}

Due to urbanization and the low birth rate in the Netherlands in recent years, the amount of children in some neighbourhoods and local communities is declining (e.g. Onderwijsraad, 2013; EIB, 2013). And because a lot of the existing school buildings were built in the 1970s and 1980 s when there was a growing number of children in the Netherlands, they are now around forty to fifty years old. The developments mentioned above showcase the need for good argumentation on how to deal with the existing stock and the need for good decision-making tools (Ritsema 2013; Tennekes et al., 2017; Ministry of I. and M. and Ministry of OCW, 2016). In the Netherlands, however, authors argue that it appears to be difficult to combine budgets and to make a coherent and integrated strategy for primary school buildings (Rodermond et al., 2009; Heijnders et al., 2015; Mol \& Broekhuizen, 2015). What theoretical possibilities school boards have to adapt buildings to their wishes is to a large extent determined by the legal possibilities that exist (Lengkeek, 2014; Tennekes et al., 2017). Due to a legislative amendment in 2015, the lifecycle approach has become more feasible (Berndsen et al., 2012; Lengkeek, 2014; VNG, 2018).

\section{Integral approach}

In the basic literature on real estate strategies, the integral approach is mentioned as one in which various aspects are taken into account: financial considerations, user requirements and building technology (Den Heijer \& Van der Voordt, 2012; see also Van Vliet, 2007; Struthman, 2012; Vos, 2015). Authors agree that an integrated approach by the stakeholders is preferable. Several studies dealing with process considerations and real estate and management point to the importance of (more) involvement of users in the design process of the primary school and propose a form of participatory design so that more alignment takes place. On the basis of theoretical literature research, De Vrieze and Moll propose a model aimed at increasing the involvement of end users in the decision-making process. In that way the balance between societal interests and end users could improve (De Vrieze \& Moll, 2015, 2017). Interestingly, participatory design does not only concern the involvement of end users in the design process, but also a permanent input: control after completion and during use. This lack of attuning not only applies to primary education, but also occurs in general in secondary and higher education in the Netherlands (Beckers et al., 2015; Koutamanis et al., 2017). Koutamanis et al. (2017) propose to intensify the use of Building Information Modelling (BIM) for secondary schools as a visual tool to involve the end users in the process: school managers, teachers and students. In practice, however, the process of participation appears to be complicated (Burke \& Konings, 2016). An Thi Hoai Le and Park (2018) conclude, on the basis of a literature review, that for the refurbishment of school buildings the use of advantages of information technology (for example 3D scanners and BIM applications) can be improved. They point out that national strategies can have a positive effect on these processes. 


\section{Discussion}

In this research, existing general strategies for adjusting real estate are nuanced for a specific area: primary schools and children's centres. The nine strategies presented explain what happens in practice in dealing with questions of conversion strategies for primary schools and children's centres. They indicate a main line, but in practice they also occur mixed or in combinations. It can be noticed that in practice, in this category of buildings there is a need for more intermediate steps. The nine strategies could help to apply the more integrated approach because they offer a more nuanced strategy than the general standard models.

This research focuses on conversion strategies for buildings for primary education, but it is expected that the strategies may also be relevant for buildings for secondary education. Questions of low birth rate, sustainability, small schools, urbanization and year of construction also play a role when dealing with secondary schools. Although the laws and regulations are different in this sector in the Netherlands, there is some overlap with other aspects that effect the requirements imposed on the buildings. Specific research into which conversion strategies apply to buildings for secondary education can provide a further fine-tuning of the scenarios for this category of buildings. When converting secondary school buildings, the use of a well thought out, coherent and integrated strategy is preferable; because of the quality of the building, but also because of cultural heritage arguments.

\section{Conclusions}

This article presents nine strategies for adaptation and change of existing primary schools and children's centres in the Netherlands. The use of these nine strategies for the physical-spatial intervention can be an improvement on the existing, general models, which are valid at an abstract level. The two categorizations - general strategies or contextual strategies - do not exclude each other, but show that in-depth analyses clarify more precise strategies. The analysis raises the question whether for a specific category, primary schools and children's centers in the Netherlands, the four basic strategies are too generic and require nuance.

\section{Acknowledgements}

During the research for this paper Dolf Broekhuizen was guest researcher at the Faculty of Architecture and the Built Environment, Delft University of Technology. The authors had informative contact with Prof.dr.ir. Sun Young Rieh (University of Seoul, Korea), Barbara Pampe (Montag Stiftung Jugend und Gesellschaft, Bonn), Milou Joosten (senior adviser Chief Government Architect, The Hague), Dr. Joost Tennekes and ir. Like Bijlsma (Netherlands Environmental Assessment Agency, The Hague), Sonja Pool (The Hague Schools, The Hague), and Dickie Gunning (Department of Education, Youth and Care, City of Amsterdam).

\section{References}

Algemene Rekenkamer. (2016). Schoolgebouwen primair en voortgezet onderwijs: de praktijk gecheckt. Algemene Rekenkamer.

An Thi Hoai Le, \& Park, K. S. (2018). Sustainable refurbishment for school buildings. A literature review. International Journal of Building Pathology and Adaption.

Beckers, R., Van der Voordt, D., \& Dewulf, G. (2015). Management strategies for aligning higher education accommodation with the user needs. Journal of Corporate Real Estate, 17(2), 80-97. https://doi.org/10.1108/JCRE-10-2014-0025

Berndsen, F. E. M., Dekker, B., \& Van Bergen, C. T. A. (2012). Onderzoek overheveling buitenonderhoud schoolgebouwen Primair Onderwijs. Eindrapport. Regioplan beleidsonderzoek in opdracht van het Ministerie van Onderwijs, Cultuur en Wetenschap.

Bluyssen, P. M., Zhang, D., Kurvers, S., Overtoom, M., \& Ortiz-Sanchez, M. (2018). Self-reported health and comfort of school children in 54 classrooms of 21 Dutch school buildings. Building and Environment, 138, 106-123.

https://doi.org/10.1016/j.buildenv.2018.04.032

Brás, A., Rocha, A., \& Faustino, P. (2015). Integrated approach for school buildings rehabilitation in a Portugese city and analysis of suitable third party financing solutions in EU. Journal of Building Engineering, 3, 79-93. https://doi.org/10.1016/j.jobe.2015.05.003

Broekhuizen, D. (2015). Verbouwingen. In D. Broekhuizen, M. H. Arkesteijn et al., Scholenbouwatlas. Verbouwen als nieuwe opgave voor basisscholen en kindcentra (pp. 68-285). Nai010 publishers.

Broekhuizen, D., Mol, A., Geertse, M., \& Van Zandwijk, M. (2015). Scholenbouw stroomlijnen. Knelpunten in de wet- en regelgeving bij de verbouw van basisscholen en kindcentra. Atelier Rijksbouwmeester.

Burke, C., \& Könings, K. D. (2016). Recovering lost histories of educational design: a case study in contemporary participatory strategies. Oxford Review of Education, 42(6), 721-732. https://doi.org/10.1080/03054985.2016.1232244

Calice, C., Clemete, C., De Santoli, L., \& Fraticelli, F. (2012). Guidelines for the retrofit of the school building stock for sustainable urban regeneration of the city of Rome. The Sustainable City, VII(1), 417-428. https://doi.org/10.2495/SC120351

De Jong, P., \& Arkesteijn, M. H. (2014). Life cycle costs of Dutch school buildings. Journal of Corporate Real Estate, 16(3), 220-234. https://doi.org/10.1108/JCRE-08-2013-0019

De Vries, J. (2007). Presteren door vastgoed. Onderzoek naar de gevolgen van vastgoedingrepen voor de prestatie van hogescholen (PhD thesis). Delft University of Technology.

De Vrieze, R., \& Moll, H. C. (2015). Crisis in Dutch primary school-building design solved by paradigm shift? Intelligent Buildings International, 7(1), 36-60. https://doi.org/10.1080/17508975.2014.943152

De Vrieze, R., \& Moll, H. C. (2017). An analytical perspective on primary school design as architectural synthesis towards the development of needs-centred guidelines. Intelligent Buildings International, 10(1), 19-41. https://doi.org/10.1080/17508975.2016.1275500

Den Heijer, A. C., \& Van der Voordt, D. J. M. (Eds.). (2012). Vastgoedmanagement. Real Estate Management, Technical University Delft, Real Estate and Housing.

Den Heijer, A. C., Van der Voordt, D. J. M., \& Heurkens, E. W. T. M. (2013). Vastgoedmanagement en Gebiedsontwikkeling. Delft University of Technology, Faculty of Architecture. 
EIB. (2013). Bouwen voor het onderwijs. Perspectief voor de Nederlandse bouw. Economisch Instituut voor de Bouw.

Emmelot, Y., Van der Veen I., \& Ledoux G. (2006). De brede school: kenmerken, verwachtingen en mogelijkheden. Pedagogiek, (1), 64-81.

Evans, H. (2015). Refurbishment and extension of existing schools'. In P. Chiles (Ed.), Building schools. Key issues for contemporary design (pp. 193-218). Birkhauser.

Heijnders, L., De Jong, P., \& Arkesteijn, M. H. (2015). Gemeente. Omgaan met de bestaande voorraad. In D. Broekhuizen, M. H. Arkesteijn et al., Scholenbouwatlas. Verbouwen als nieuwe opgave voor basisscholen en kindcentra (pp. 58-61). Nai010 publishers.

Kempinga, W., \& Feddes, F. (2017). De school voor kind en gemeenschap. In A. Blom (Ed.), Wederopbouw, een kansrijke erfenis. Handreiking bij transformatieopgaven (pp. 86-94). Amersfoort RCE 2017.

Koutamanis, A., Heuer, J., \& Könings, K. D. (2017). A visual information tool for user participation during the lifecycle of school building design: BIM. European Journal of Education, 52, 295-305. https://doi.org/10.1111/ejed.12226

Lengkeek, W. (2014). Strategisch omgaan met onderwijshuisvesting vanaf 2015. Pica onderwijsmanagement.

Ministry of Infrastructure and the Environment (I. and M.) \& Ministry of Education, Culture and Science (OCW). (2016). Working together on the strenght of design. Action Agenda for spatial design 2017-2020. Ministry of I. and M. and OCW.

Mol, A., \& Broekhuizen, D. (2015). Spieken mag! Kansen en belemmeringen in wet- en regelgeving bij scholenbouw. In D. Broekhuizen, M. H. Arkesteijn et al., Scholenbouwatlas. Verbouwen als nieuwe opgave voor basisscholen en kindcentra (pp. 21-25). Nai010 publishers.

Montag Stiftung. (2012). Schulumbau. Stategien zur Anpasung von Bestandsgebäuden. Montag Stiftung Urbane Räume, Montag Stiftung Jugend und Gesellschaft.

Montag Stiftung Jugend und Gesellschaft. (Ed.). (2017). Schulen Plannen und Bauen 2.0. Grundlagen, Prozesse, Projekte. Jovis/ Seelze, Friedrich.

Onderwijsraad. (2013). Grenzen aan kleine scholen. Onderwijsraad.

Österreicher, D., \& Geissler, S. (2016). Refurbishment in educational buildings - methodological approach for high performance integrated school refurbishment actions. Energy Procedia, 96, 375-385. https://doi.org/10.1016/j.egypro.2016.09.163

Prins, M. (1992). Flexibiliteit en kosten in het ontwerpproces: een besluitvormingsondersteunend model. Eindhoven University of Technology.

Ritsema, G. H. (2013). Kind-centra(al) in onderwijshuisvesting. Amsterdam School of Real Estate, Master of Science in Real Estate.

Rodermond, J., Wallagh, G., \& Van der Leun, A. (2009). Geen meter teveel. Agenda Scholenbouw. Creative Industries Fund.
Scottish Government. (2009). Building better schools: Investing in Scotland's future. The Scottish Government.

SER. (2016). Gelijk goed van start. Visie op het toekomstige stelsel van voorzieningen voor jonge kinderen. Advies Sociaal Economische Raad.

Stocker, E., Tschurtschenthaler, M., \& Schrott, L. (2015). Costoptimal renovation and energy performance: Evidence from existing school buildings in the Alps. Energy and Buildings, 100, 20-26. https://doi.org/10.1016/j.enbuild.2015.04.005

Struthman, S. P. J. (2012). Koppelen van de gemeentelijke organisatiedoelstellingen aan de vastgoedstrategie (Master thesis). Delft University of Technology.

Tennekes, J., Van Amsterdam, H., \& Bijlsma, L. A. O. (2017). Maatschappelijk vastgoed in verandering. Ruimtelijke dynamiek van woonzorggebouwen en basisscholen en de gevolgen van vraagvolgende bekostiging. Planbureau voor de Leefomgeving.

Tondeur, J., De Bruyne, E., Van Den Driessche, M., McKenney, S., \& Zandvliet, D. (2015). The physical placement of classroom technology and its influences on educational practices. Cambridge Journal of Education, 45(4), 537-556. https://doi.org/10.1080/0305764X.2014.998624

Van Dam, S., \& Spoormans, L. (2011). De gehanteerde principes van transformatie. In S. Van Dam, S. Komossa, \& L. Spoormans (Eds.), De transformatie van het schoolgebouw. Thoth.

Van der Pol, L., Mol, A., \& Broekhuizen, D. (2009). Gezond en goed. Scholenbouw in topconditie. Atelier Rijksbouwmeester.

Van Nieuwamerongen, Fr., \& Abraham, R. (2012). De grote schoolverbouwing. De meerwaarde van schooltransformaties in het basisonderwijs. In Lay-out 20. Platform voor recent ontwerpend onderzoek. Creative Industries Fund.

Van Nieuwamerongen, Fr., \& Broekhuizen, D. (2015). Modellen van verandering. Verbouwmodellen voor basisscholen en kinderopvang. D. Broekhuizen, M. H. Arkesteijn et al., Scholenbouwatlas. Verbouwen als nieuwe opgave voor basisscholen en kindcentra (pp. 26-33). Nai010 publishers.

Van Merriënboer, J. J. G., McKenney, S., Cullinan, D., \& Heuer, J. (2014). Aligning pedagogy with physical learning spaces. European Journal of Education, 52, 253-267.

https://doi.org/10.1111/ejed.12225

Van Vliet, L. (2007). De bijdrage van vastgoed aan de organisatieprestatie (Master thesis). Delft University of Technology.

Vermeulen, M., \& Wieman, M. (2010). Handboek vastgoedmanagement. Noordhoff Uitgevers.

Vermeulen, M., \& Wieman, M. (2016). Vastgoedexploitatie. Noordhoff Uitgevers.

VNG. (2018). Modelverordening voorzieningen huisvesting onderwijs - na update 2017. https://vng.nl

Vos, D. (2015). Empty schools. Quantitative research on hidden vacancy among primary schools in the Netherlands (Master thesis). Delft University of Technology. 